PERM JOURNAL OF PETROLEUM AND MINING ENGINEERING

ВЕСТНИК ПНИПУ. ГЕОЛОГИЯ. НЕФТЕЕАЗОВОЕ И ГОРНОЕ ДЕЛО

ISSN 2224-9923

Volume / Tom 16 №4 2017

http://vestnik:pstu.ru/geo/

УДК 662.749.319:539.215.4:620.193.94

Article / Статья

(C) PNRPU / ПНИПУ, 2017

\title{
DISPERSION OF THE G-TYPE COAL DUST OF THE VORGASHORSKOE FIELD AND ITS INFLUENCE ON THE THERMAL DESTRUCTION PROCESS
}

\section{Vladimir A. Rodionov, Leonid V. Pikhkonen, Sergey Ya. Zhikharev ${ }^{1}$}

Saint Petersburg University of State Fire Service of EMERCOM of Russia (149 Moskovskiy av., Saint Petersburg, 199105, Russian Federation) ${ }^{1}$ Mining Institute of the Ural Branch of the Russian Academy of Sciences (78 Sibirskaya st., Building A, Perm, 614007, Russian Federation)

\section{ДИСПЕРСНОСТЬ КАМЕННОУГОЛЬНОЙ ПЫЛИ МАРКИ Ж ВОРГАШОРСКОГО МЕСТОРОЖДЕНИЯ И ЕЁ ВЛИЯНИЕ НА ПРОЦЕСС ТЕРМИЧЕСКОЙ ДЕСТРУКЦИИ}

\section{В.А. Родионов, Л.В. Пихконен, С.Я. Жихарев ${ }^{1}$}

Санкт-Петербургский университет государственной противопожарной службы МЧС РФ (196105, Россия,

г. Санкт-Петербург, Московский пр., 149)

${ }^{1}$ Горный институт Уральского отделения Российской академии наук (614007, Россия, г. Пермь, ул. Сибирская, 78a)

Received / Получена: 31.08.2017. Accepted / Принята: 12.10.2017. Published / Опубликована: 01.12.2017

Key words:

granulometric analysis, technical analysis, dispersion composition, pyrolysis of coal, explosive dust, coal dust, differential thermal analysis, thermogravimetry.
Results of a comprehensive study of coal dust obtained from the G-type coal of Vorgashorskoe field are presented. The main research methods used in the work are granulometric, thermogravimetric and differential thermal analysis.

The granulometric sieving carried out confirmed the heterogeneity of the sample with size of $0-200 \mu \mathrm{m}$ fraction for a technical analysis. It is established that fractions of less than $100 \mu \mathrm{m}$ size account for more than $50 \%$ of the total sample mass. The results obtained suggested that result can be different depending on the content of a fraction in the overall technical sample sent for an analysis. However, this is probably acceptable in a technical analysis of coal dust samples but not for determination of explosive and fire hazard indicators. In order to study the effect of the dispersion composition of dust on a pyrolysis process in the air (oxidizing) medium for each of the fractions of $0-200 \mu \mathrm{m}$ and additionally for larger fractions studies were carried out using thermogravimetry and a differential thermal analysis

The thermogravimetric analysis confirmed the hypothesis about the ambiguous behavior of coal dust during its pyrolysis depending on the dispersion composition. Two fractions showed the same behaviont during the thermal pyrolysis. The fraction of $63-94 \mu \mathrm{m}$ is the boundary one between 0-45 and 45-63 $\mu \mathrm{m}$ and remaining fractions of larger than $94 \mu \mathrm{m}$ in size. That fact indicates that during determination of the explosive fire hazard properties it is necessary to investigate dust samples of dispersive composition from 0 to $100 \mu \mathrm{m}$, i.e. a narrower fraction than in the technical analysis of samples from 0 to $200 \mu \mathrm{m}$. Express analysis of the obtained data of differential thermal analysis showed a difference in thermal degradation between the fractions of interest at the initial stage $\left(250-330^{\circ} \mathrm{C}\right)$. The results obtained allowed to draw a conclusion about the expediency of the study of coal dust of dispersive composition from $0-100 \mu \mathrm{m}$. It also showed the necessity of using methods considered in the paper for a detailed study of physical and chemical parameters of coal dust and an assessment of its explosive and fire hazard properties.
Ключевые слова: гранулометрический анализ, технический анализ, дисперсионный состав, пиролиз каменного угля, взрывоопасная пыль, угольная пыль, дифференциальнотермический анализ, термогравиметрия.
Изложены результаты комплексного исследования каменноугольной пыли, полученной из каменного угля марки Ж Воргашорского месторождения. Основными методами исследования, примененными в работе, были методы гранулометрического, термогравиметрического и дифференциально-термического анализа.

Проведенный гранулометрический рассев подтвердил неоднородность пробы размером фракции 0-200 мкм для технического анализа. Установлено, что на долю фракций размером менее 100 мкм приходится более 50 \% от общей массы пробы. Полученные результаты позволили предположить, что в зависимости от содержания той или иной фракции в общей технической пробе, направленной на анализ, результат может быть различным. Однако при выполнении технического анализа пробы каменноугольной пыли, возможно, это и допустимо, а при определении взрывопожароопасных показателей нет. С целью изучения влияния дисперсионного состава пыли на процесс пиролиза в воздушной (окислительной) среде для каждой из фракций 0-200 мкм и дополнительно для более крупных фракций были выполнены исследования методами термогравиметрии и проведен дифференциально-термический анализ. Данные термогравиметрического анализа подтвердили предположение о неоднозначном поведении каменноугольной пыли при ее пиролизе в зависимости от дисперсионного состава. Две фракции показали одинаковое поведение при термическом разложении, фракщия 63-94 мкм является пограничной фракцией между 0-45 и 45-63 мкм и остальными фракциями большего, чем 94 мкм, размера. Данный факт пограничной фракцией между 0-45 и 45-63 мкм и остальными фракциями большего, чем 94 мкм, размера. Данный факт
свидетельствует о том, что при определении взрывопожароопасных свойств необходимо исследовать пробы пыли дисперсионного состава от 0 до 100 мкм, т.е. более узкую фракцию, чем при проведении технического анализа проб от 0 до 200 мкм. Экспресс-анализ полученных данных дифференциально-термического анализа показал разницу при термической деструкции между рассматриваемыми фракциями на начальном этапе $\left(250-330{ }^{\circ} \mathrm{C}\right)$. Полученные результаты позволили сделать вывод о целесообразности исследования каменноугольной пыли дисперсионного состава от 0-100 мкм, а также показали необходимость применения рассмотренных в статье методов для детального изучения физико-химических параметров угольной пыли и оценки ее взрывопожароопасных свойств.

Vladimir A. Rodionov - PhD in Engineering, Associate Professor, Doctorate Student at the Faculty of Highly Qualified Personnel Training (mob. tel.: +007 9213258397, e-mail: 79213258397@mail.ru).The contact person for correspondence.

Leonid V. Pikhkonen - PhD in Engineering, Head of the Department of Mine Rescue and Explosion Safety (mob. tel.: +007 921 325 83 97, e-mail: igpsmining@list.ru). Sergey Ya. Zhikharev - Doctor of Engineering, Chief Research Fellow (mob. tel.: +007919 45109 51, e-mail: perevoloki55@mail.ru)

Родионов Владимир Алексеевич - кандидат технических наук, доцент, докторант факультета подготовки кадров высшей квалификации (моб. тел.: +007 9213258397, e-mail: 79213258397@mail.ru). Контактное лицо для переписки.

Пихконен Леонид Валентинович - кандидат технических наук, заведующий кафедрой горноспасательного дела и взрывобезопасности (моб. тел.: +007 9213258397 , e-mail: igpsmining@list.ru).

Жихарев Сергей Яковлевич - доктор технических наук, главный научный сотрудник (моб. тел.: +007 919 451 09 51, e-mail: perevoloki55@mail.ru). 


\section{Introduction}

In order to assess the quality of coal a technical analysis is carried out using known standard techniques. The study object is not the coal itself but samples dispersed to a fraction of 0-200 (212) $\mu \mathrm{m}$ [1-7].

Such a wide range where technical parameters and explosive \& fire hazard properties are recommended to determine is defined in the current standards. Many researchers have studied the influence of the dispersion composition of coal on its fire-fighting properties well enough. Most papers prove that the lowest the fractions the highest the explosion hazard [8-10]. However, only with use of modern instruments and equipment that allow to use thermogravimetric (TG) and differential-thermal (DTA) analysis it has become possible to identify new quantitative and qualitative dependencies of the effect of the dispersion composition of coal dust on the pyrolysis process. The experimental data obtained by us indicate that the localization of the dispersion composition of coal dust changes its explosive and fire hazard properties [8-15].

Over the past few years coal mining has grown, which led to an increase in emergency situations, including fatal (mass death of miners) [16-19]. These circumstances indicate the need to find new approaches to solving industrial and fire safety issues related to ensuring security at the facilities of the mineral and raw materials complex [20-26].

One of the solutions aimed at improving fire and industrial safety is the application of modern scientific methods for determining technical indicators of coal as raw materials, as well as its explosive and fire hazard properties [27-31]. Taking into account that studies were not conducted to determine the explosive and fire hazard properties aimed at studying the behavior of coal dust of different fractions (from 0 to $200 \mu \mathrm{m}$ ), we attempted to investigate the pyrolysis of individual fractions in an oxidizing medium.

\section{Objective}

Carry out the dispersion analysis of standard samples prepared for technical analysis and evaluate the impact on the process of pyrolysis in the oxidizing environment of each fraction of coal dust of G-type coal.

\section{Object of study}

The object of the study were samples of G-type coal from the Vorgashorskoe field, dispersed and scattered into fractions. Fractional compositions are $0-45,45-63,63-94,94-125,125-140,140-200$, 200-250 and 250-315 $\mu \mathrm{m}$.

\section{Methods and procedures of study}

In order to achieve the goals we applied methods of analysis of variance, dry granulometric sieving and methods of thermogravimetry and differential thermal analysis.

G-type coal from Vorgashorskoe field was sampled for the study. A selected sample of coal was prepared for grinding on the vibratory cone mill-crusher VKMD-10. After grinding, the obtained dispersed mass of coal was directed to dry sieving.

The Fig. 1 shows the appearance of the analytical sieve machine series AS 200 produced by Retsch.

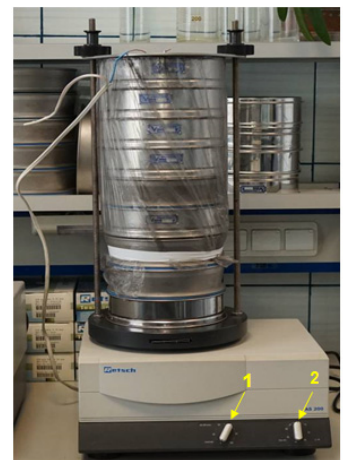

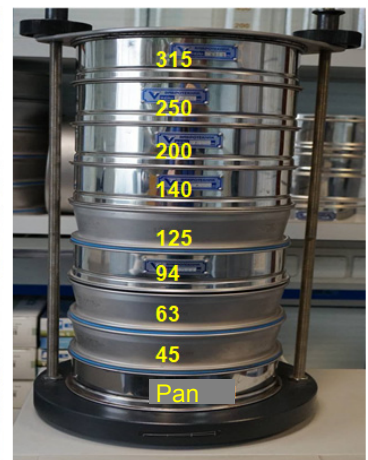

Fig. 1. The look of the sieving machine with a ground electrode for the static electricity generated: 1 - vibration shifter; 2 - adjustment of sieving time (a); an enlarged set of sieves indicating the sieve cell $(b)$

This type of scattering machine provides a smooth, unstressed way of sieving. With an unstressed sieving method, the cells are practically not clogged and are easily cleaned of residues. Since there is no effect of "punching" of particles in the impact sieving method, fractions are obtained in more rigorous forms with respect to the dispersion parameters.

Results of granulometric sieving of the selected sample of G-type coal, ground by VKMD-10, are given in the table.

It can be seen from the table that fractional composition is not homogeneous. There are $32.77 \%$ for share of the fraction 63-94 and more than $55 \%$ 
for fractions less than 94 microns. The data obtained confirm the need to study the explosive-fire hazard properties of smaller dust fractions but not just those of dispersion less than $212 \mu \mathrm{m}$.

Results of the screening of a sample of G-type coal from Vorgashorskoe field

\begin{tabular}{|c|c|}
\hline Dispersion of fraction, $\mu \mathrm{m}$ & Fraction output, $\%$ \\
\hline $0-45$ & 3.78 \\
\hline $45-63$ & 18.56 \\
\hline $63-94$ & 32.77 \\
\hline $94-125$ & 14.58 \\
\hline $125-140$ & 9.74 \\
\hline $140-200$ & 20.55 \\
\hline
\end{tabular}

Further studies of the pyrolysis process were carried out on the STA 449 F3 Jupiter unit. Air (oxidizer-oxygen of air) is chosen as the oxidizing medium. Experimental conditions are chosen taking into account results of previous researchers and available techniques for the thermogravimetric analysis. The installation represents a combined TGA/DSC/CTA-analyzer, STA 449 F3 Jupiter, running under the NETZSCH Proteus Termal Analysis software package. During the experiments, thermogravimetric, differential-thermal analysis and software express processing of the obtained data were used.

The choice of test conditions and applied methods is based on the analysis of papers and regulatory data [32-41].

Test conditions: thermocouple (module) - type S; mass of sample $-10 \mathrm{mg}$; heating rate is $20^{\circ} \mathrm{C} / \mathrm{min}$; gas flow rate (air) - 40/60 $\mathrm{ml} / \mathrm{min}$; final heating temperature $-900{ }^{\circ} \mathrm{C}$; thermostating for $10 \mathrm{~min}$ at $900^{\circ} \mathrm{C}$ and cooling; oxidizing medium - air.

The Fig. 2 presents the result of the thermogravimetric study of the pyrolysis process of fractions $0-45,45-63,63-94,94-125,125-140$, 140-200. In addition, larger dust fractions, in particular 200-250 and 250-315 $\mu \mathrm{m}$, are also shown in the Fig. 2.

It can be seen from the data shown in Fig. 2, that the TG curves divided into three groups and DTA curves also formed three groups with a fractional composition similar to the TG groups.

The first group included fractions of $0-45 \mu \mathrm{m}$ (black curve) and 45-63 $\mu \mathrm{m}$ (lilac curve). The second curve, which is the "boundary" between the first and third groups, is represented only by the fraction 63-94 $\mu \mathrm{m}$ (red curve). The third large group of coincided (overlapping) curves is made up of the remaining fractions: 94-125, 125-140,
140-200, 200-250 and 250-315 $\mu \mathrm{m}$ (lower in Fig. 3 and 4 , the third group is represented by fraction 250-315 $\mu \mathrm{m}$ of blue color). To be clear and have possibility of comparing the results of the TG and DTA analyzes in Fig. 3 and 4, the curves of the same fraction have the same color as in Fig. 1. The black color corresponds to a coal dust fraction with a dispersion of $0-45 \mu \mathrm{m}$, a red color of $63-94 \mu \mathrm{m}$ and a blue color of $250-315 \mu \mathrm{m}$.

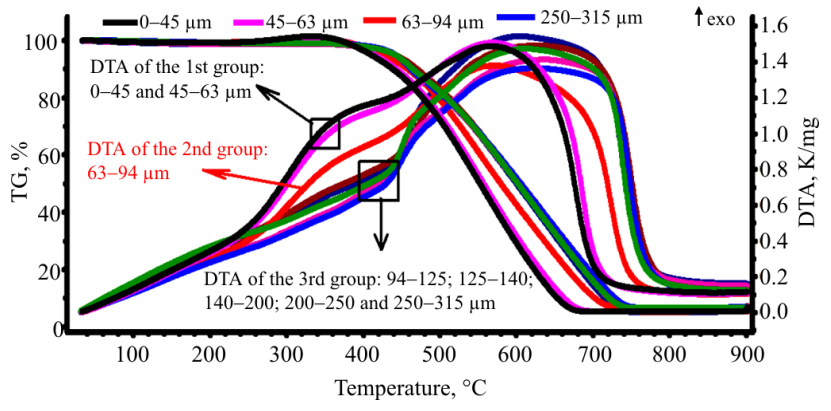

Fig. 2. Graphs of thermogravimetric and differential-thermal analysis of samples of coal dust of different dispersity

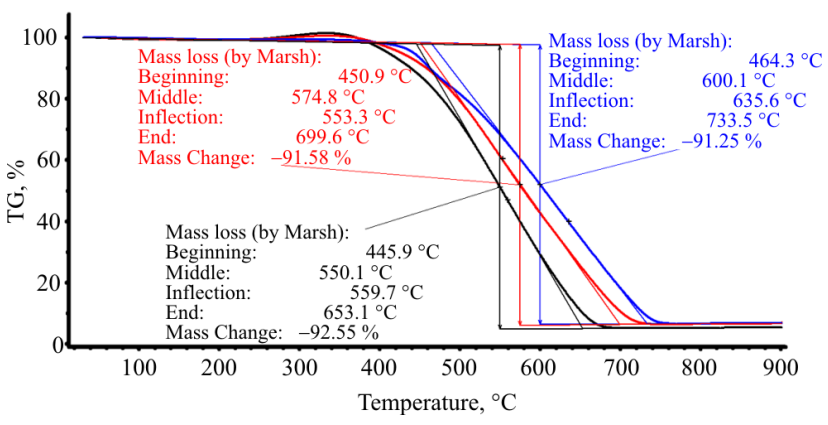

Fig. 3. Graphical display of thermogravimetric analysis data for coal dust samples with a dispersion of 0-45 (black), 63-94 (red) and 250-315 (blue curve) $\mu \mathrm{m}$

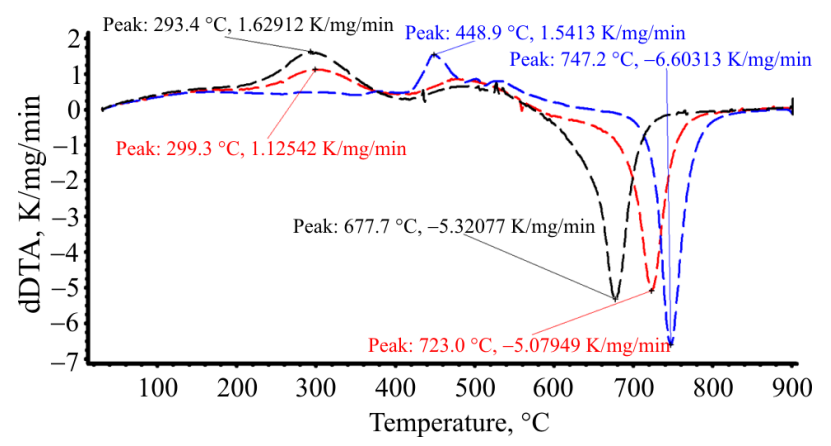

Fig. 4. The results of program express processing of the dDTA curves using the NETZSCH Proteus Termal Analysis software package: 0-45 $\mu \mathrm{m}$ - black, 63-94 $\mu \mathrm{m}$ - red and 250-315 $\mu \mathrm{m}$ - blue curve

The results obtained confirmed the assumption of ambiguity of the behavior of coal dust as a function of its dispersity under heating conditions in an air (oxidizing) medium. In addition, results of TG and 
DTA analysis have shown the need to study narrow fractions, rather than the fraction $0-212 \mu \mathrm{m}$, as prescribed by regulatory documents [3-7, 13].

The results of program express processing of TG curves using the NETZSCH Proteus Termal Analysis software are shown in the Fig. 3.

According to the express data of the software analysis, shown in the Fig. 3, it can be seen that the beginning of the thermal destruction of samples of fraction $\quad 0-45$ and 63-94 $\mu \mathrm{m}$ completely coincides. The set of mass in the temperature range 250-350 ${ }^{\circ} \mathrm{C}$ indicates a possible appearance of a focus of smoldering. The exact temperature of smoldering can be determined by comparing the data of thermogravimetric (TG), differentialthermogravimetric (DTG) and/or differentialthermal analysis by the first derivative (dTA) [34-36]. For all other fractions, an increase in mass and heating of the sample is not observed, but the decrease in mass begins at a temperature of $400{ }^{\circ} \mathrm{C}$, i.e. at least $50{ }^{\circ} \mathrm{C}$ later. In addition, some papers suggest that the inflection point corresponds to the maximum yield of volatiles and the autoignition temperature of the substance $[32,34-36]$. Consequently, if we rely on fractional composition data without knowledge of the proportional relationship between the fractions and thermal characteristics of each fraction, the reliability of evaluation of explosive-fire properties of coal dust is underestimated significantly.

The Fig. 4 shows results of differential-thermal analysis for the first derivative. They also confirm our assumptions about the predominant role of finely dispersed fractions in the initiation of oxidationreduction processes, which lead to the appearance of focus of smoldering at lower temperatures.

The Fig. 4 shows dTA curves, in which, in contrast to DTA curves presented in the Fig. 1, it is possible to better visualize endo- and exothermic effects occurring in the sample under study.

In samples with a dispersion of 0-45 and 63-94 $\mu \mathrm{m}$ heat release starts from $175^{\circ} \mathrm{C}$, which, according to our assumptions, leads at a temperature of $293{ }^{\circ} \mathrm{C}$ (fraction 0-45 $\mu \mathrm{m}$ ) and $299^{\circ} \mathrm{C}$ (fraction 63-94 $\mu \mathrm{m}$ ) to the appearance of smoldering in these samples of coal dust. The results correlate well with reference values of temperatures of decay, but this can be reliably confirmed only after carrying out an additional experiment to determine the temperature of smoldering by the standard procedure and comparing the values obtained.

For all other samples with a dispersion greater than $94 \mu \mathrm{m}$, the sample heating starts at $420{ }^{\circ} \mathrm{C}$ and exothermic peak is determined at a temperature of $448.9{ }^{\circ} \mathrm{C}$. The difference between the peaks in samples 0-45, 63-94 and $94 \mu \mathrm{m}$ and above is about $150{ }^{\circ} \mathrm{C}$ which is significant. Besides, the maximum exothermic effect of samples with a smaller dispersion is also observed at a lower temperature of $677.7^{\circ} \mathrm{C}$ than in all other samples with a dispersion greater than $94 \mu \mathrm{m}$ (94$125,125-140,140-200,200-250$ and 250-315 $\mu \mathrm{m}$ ).

\section{Conclusions}

1. In order to increase the reliability of the data of technical analysis it is necessary to apply a dispersion passport to them, i.e. to provide the data of granulometric analysis of the sample sent for technical analysis in the accompanying documentation.

2. That is proposed during determination of explosion and fire hazard properties of carboniferous dust samples to carry out with samples of fractional composition $0-100 \mu \mathrm{m}$, rather than $0-212(200) \mu \mathrm{m}$, as recommended in $[3-7,13]$ and a number of other regulatory documents.

3. Methods of thermogravimetric and differential thermal analysis with their joint interpretation allow to state the explosive and fire hazard properties of coal dust during its pyrolysis in the air. That requires the development of a package of regulatory legal documents that establish requirements for methods for determining explosive and fire hazard properties of coal dust using thermogravimetric and differential thermal analysis.

\section{References}

1. Chernysheva E.A. Vlaga $v$ ugliakh kak parametr kachestva produktsii [Moisture in the coals as a parameter of product quality]. Ugol', 2016, no.8, pp.125-128. DOI: $10.18796 / 0041-5790-2016-8-125-128$

2. Coal dust, available at: http://monographs.iarc.fr/ ENG/Monographs/vol68/mono68-12.pdf (accessed: 20 June 2017).

3. GOST 33654-2015. Ugli burye, kamennye i antratsit. Obshchie trebovaniia k metodam analiza [Coals are brown, stone and anthracite. General requirements for analysis methods], available at: http://www.internetlaw.ru/gosts/gost/61802/ (accessed: 20 June 2017).

4. GOST R 55661-2013. Toplivo tverdoe mineral'noe. Opredelenie zol'nosti [Solid mineral fuel. Determination of ash content], available at: http://www.internetlaw.ru/gosts/gost/55374/ (accessed: 20 June 2017).

5. GOST R 55660-2013. Toplivo tverdoe mineral'noe. Opredelenie vykhoda letuchikh veshchestv [Solid mineral 
fuel. Determination of the yield of volatile substances], available at: http://www.internet-law.ru/gosts/gost/55585 (accessed: 20 June 2017).

6. GOST 33623-2015. Toplivo tverdoe mineral'noe. Metod opredeleniia ravnovesnoi vlazhnosti [Solid mineral fuel. Method for determination of equilibrium moisture], available at: http://www.internet-law.ru/gosts/gost/61798/ (accessed: 20 June 2017).

7. GOST 33503-2015. Toplivo tverdoe mineral'noe. Metody opredeleniia vlagi $\mathrm{v}$ analiticheskoi probe [Solid mineral fuel. Methods for determining moisture in an analytical sample], available at: http://www.internetlaw.ru/gosts/gost/61865/ (accessed: 20 June 2017).

8. Korol'chenko A.Ia. Pozharovzryvoopasnost' promyshlennoi pyli [Fire and explosion hazard of industrial dust]. Moscow, Khimiia, 1986, 216 p.

9. Airuni A.T., Klebanov F.S., Smirnov O.V. Vzryvoopasnost' ugol'nykh shakht [Explosiveness of coal mines]. Moscow, Gornoe delo, Kimmeriiskii tsentr, 2011, 264 p.

10. Kaliakin S.A., Bulgakov Iu.F. Pozharovzryvoopasnost' otlozhenii ugol'noi pyli [Fire and explosion hazard of coal dust deposits]. Nauchnyi vestnik NIIGD Respirator, 2012, no. 1, pp.14-27.

11. Kaliakin S.A. Analiz pozharovzryvoopasnosti ugol'noi pyli [Analysis of fire and explosion hazard of coal dust]. Nauchnyi vestnik NIIGD Respirator, 2012, no.1, pp.27-35.

12. Tekhnicheskii reglament o trebovaniiakh pozharnoi bezopasnosti [Technical regulations on fire safety requirements]. Federal'nyi zakon ot 22 iiulia 2008 goda no. 123-FZ (s izmeneniiami na 29 iiulia 2017 goda), available at: http://www.consultant.ru/document/cons doc_LAW 78699/ (accessed: 20 June 2017).

13. GOST 12.1.044-89. Pozharovzryvoopasnost' veshchestv i materialov. Nomenklatura pokazatelei i metody ikh opredeleniia (s izmeneniem no.1) [Fire and explosion hazard of substances and materials. Nomenclature of indicators and methods for determining them (with the change No. 1)], available at: http://npopris.ru/wp-content/uploads/2015/03/ ГOCT-12.1.044-89.pdf (accessed: 20 June 2017).

14. Baratov A.N., Korol'chenko A.Ia., Kravchuk G.N. et al. Pozharovzryvoopasnost' veshchestv i materialov $\mathrm{i}$ sredstva ikh tusheniia [Fire and explosion hazard of substances and materials and their extinguishing agents]. Moscow, Khimiia, 1990.

15. Korol'chenko A.Ia., Korol'chenko D.A. Pozharovzryvoopasnost' veshchestv i materialov i sredstva ikh tusheniia [Fire and explosion hazard of substances and materials and their extinguishing agents]. Moscow, Pozhnauka, 2004.

16. Informatsionnyi biulleten' Federal'noi sluzhby po ekologicheskomu, tekhnologicheskomu i atomnomu nadzoru [Information Bulletin of the Federal Service for Environmental, Technological and Nuclear Supervision]. Upravlenie po nadzoru $\mathrm{v}$ ugol'noi promyshlennosti. Ugol'naia promyshlennost', 2016, no. 4 (85), pp.1-7.

17. Tarzanov I.G. Itogi raboty ugol'noi promyshlennosti Rossii za ianvar' - dekabr' 2015 goda [Results of the work of the Russian coal industry in JanuaryDecember 2015]. Ugol', 2015, no.3, pp.58-72. DOI: $10.18796 / 0041-5790-2015-12-58-72$
18. Tarzanov I.G. Itogi raboty ugol'noi promyshlennosti za ianvar' - iiun' Rossii 2016 goda [Results of the work of the coal industry in January-June of Russia in 2016]. Ugol', 2016, no.9, pp.46-62. DOI: $10.18796 / 0041-5790-2016-9-46-62$

19. Nosenko V.D. Kak iskliuchit' vzryvy metana v shakhte [How to exclude methane explosions in the mine]. Ugol', 2016, no.6, pp.37.

20. Babkin V.A. Razvitie ugol'noi promyshlennosti Rossiiskoi Federatsii na primere innovatsionnogo klastera Kemerovskoi oblasti "Kompleksnaia pererabotka uglia i tekhnogennykh otkhodov" [Development of the coal industry of the Russian Federation on the example of the innovative cluster of the Kemerovo region "Complex processing of coal and man-made waste"]. Ugol', 2016, no.3, pp.46-62. DOI: 10.18796/0041-5790-2016-3-50-52

21. Promyshlennaia bezopasnost' predpriiatii mineral'no-syr'evogo kompleksa v XXI veke [Industrial safety of enterprises of the mineral and raw materials complex in the $21^{\text {st }}$ century]. Bezopasnost $t^{\prime}$ truda $v$ promyshlennosti, 2017, no.1, pp.82-87.

22. Zaburdiaev V.S. Tekhnologicheskie resheniia po predotvrashcheniiu obrazovaniia vzryvoopasnykh smesei $\mathrm{v}$ shakhtakh [Technological solutions for the prevention of the formation of explosive mixtures in mines]. Bezopasnost truda $v$ promyshlennosti, 2016, no.12, pp.26-31.

23. Mashintsov U.A., Kotlerevskaia L.V., Krinichnaia N.A. Tekhnologiia povysheniia bezopasnosti v ugol'noi shakhte [Technology of increasing safety in a coal mine]. Izvestiia Tul'skogo gosudarstvennogo universiteta. Tekhnicheskie nauki, 2014, iss.9, part 2, pp.168-172.

24. Ordin A.A. O neobkhodimosti izmeneniia gornogo zakonodatel'stva i normativnykh aktov dlia predotvrashcheniia vzryvovo metana na ugol'nykh shakhtakh Rossii [On the need to change mining legislation and regulations to prevent explosive methane from coal mines in Russia]. Ugol', 2016, no.6, pp.38-41. DOI: 10.18796/0041-5790-2016-6-38-41

25. Zeyang Song, Claudia Kuenzer. Coal fires in China over the last decade: A comprehensive review. International Journal of Coal Geology, 2014, vol.133, 1, pp.72-99. DOI: 10.1016/j.coal.2014.09.004

26. Karaoulis M., Revil A., Mao D. Localization of a coal seam fire using combined self-potential and resistivity data. International Journal of Coal Geology, 2014, vol.128-129, pp.109-118. DOI: 10.1016/j.coal.2014.04.011

27. Boiko E.A. Kompleksnyi termicheskii analiz tverdykh organicheskikh topliv [Complex thermal analysis of solid organic fuels]. Krasnoiarsk, 2006, 407 p.

28. Sazanov Iu.N. Termicheskii analiz organicheskikh soedinenii [Thermal analysis of organic compounds]. Saint Petersburg, Izdatel'stvo Politekhnicheskogo universiteta, 2016, 368 p.

29. Brown M.E., Gallagher P.K. (Eds). The handbook of Thermal. Anal. Amsterdam, Elsev., 2008, vol.5, 827 p.

30. Maryandyshev P.A., Chernov A.A., Lyubov V.K. Thermogravimetric and kinetic investigations of peat and hydrolytic lignine. International Journal of Experimental Education, 2014, no.12, pp.20-27.

31. Xue Y., Liu J., Liang J. Correlative study of critical reactions in polyacrylonitrile based carbon fiber precursors during thermal-oxidative stabilization. Polymer 
Degradation and Stability, 2013, vol.98, pp.219-229. DOI: 10.1016/j.polymdegradstab.2012.10.018

32. Cherniavskii N.V., Kosiachkov A.V., Filippenko Iu.N., Rudavina E.V., Voronov A.N. Sovershenstvovanie trebovanii $\mathrm{k}$ pokazateliam uglei dlia pylevidnogo szhiganiia na TES i metodov ikh oprobovaniia [Improvement of requirements for coal indicators for pulverized combustion at TPPs and methods for their testing]. Tekhnicheskaia teplofizika i promyslovaia teploenergetika, 2013, iss.5, pp.137-149.

33. Uendlandt U. Thermal methods of analysis. Moscow, Mir, 1978, 526 p.

34. Dashko L.V., Dovbnia A.V., Kliuchnikov V.Iu., Plotnikova G.V. Primenenie metodov termicheskogo analiza pri proizvodstve pozharno-tekhnicheskikh ekspertiz [Application of thermal analysis methods in the production of fire-technical expertise]. Vestnik Vostochno-Sibirskogo instituta MVD Rossii, 2012, № 1 (60), pp.59-64.

35. Andreeva E.D., Printseva M.Iu., Kondrat'ev S.A., Cheshko I.D. Primenenie termicheskogo analiza pri issledovanii i ekspertize pozharov: metodicheskie rekomendatsii [Application of thermal analysis in the study and examination of fires: guidelines]. Moscow, VNIIPO, 2013, $60 \mathrm{p}$.

36. Cheshko I.D. Ekspertiza pozharov (ob"ekty, metody, metodiki issledovaniia) [Examination of fires (objects, methods, research methods)]. Ed. N.A. Andreev. Saint Petersburg, SPbIPB MVD Rossii, 1997, 562 p.

37. Weiguoa Cao, Liyuana Huang, Jianxinb Zhang, Sen $\mathrm{Xu}$, Shanshana Qiu, Feng Pan. Research on characteristic parameters of coal dust explosion. Procedia Engineering, 2012, vol.45, pp.442-447. DOI: 10.1016/j.proeng.2012.08.183

38. Melody S.M., Johnston F.H. Coal mine fires and human healf: What do we now? International Journal of Coal Geology, 2015, 152, pp.1-14. DOI: 10.1016/j.coal.2015.11.001

39. Tolvanen H., Kokko L., Raiko R. Fast pyrolysis of coal, peat, and torrefied wood: Mass loss study with a drop tube reactor, particle geometry analysis, and kinetics modeling. Fuel, 2013, vol.111, pp.148-165. DOI: 10.1016/j.fuel.2013.04.030.

40. Filho S., Gomes C., Milioli F.E. A thermogravimetric analysis of the combustion of a Brazilian mineral coal. Quim. Nova, 2008, vol.31, no.1, pp.98-103, available at: $<$ http://www.scielo.br/scielo.php?script=sci arttext\&pid=S01 00-40422008000100021\&lng=en\&nrm=iso $>$ (accessed: 20 June 2017).

41. GOST R 56721-2015. Plastmassy. Termogravimetriia polimerov. Part 1. Obshchie printsipy [Plastics. Thermogravimetry of polymers. Part 1. General principles], available at: http:// www.internet-law.ru/gosts/gost/61681/ (accessed: 20 June 2017).

\section{Библиографический список}

1. Чернышева Е.А. Влага в углях как параметр качества продукции // Уголь. - 2016. - № 8. - С. 125128. DOI: 10.18796/0041-5790-2016-8-125-128

2. Coal dust [Электронный pecypc]. - URL: http://monographs.iarc.fr/ENG/Monographs/vol68/mono6 8-12.pdf (дата обращения: 20.06.2017).

3. ГОСТ 33654-2015. Угли бурые, каменные и антрацит. Общие требования к методам анализа [Электронный pecypc]. - URL: http://www.internetlaw.ru/gosts/gost/61802/ (дата обращения: 20.06.2017).

4. ГОСТ Р 55661-2013. Топливо твердое минеральное. Определение зольности [Электронный pecypc]. - URL: http://www.internet-law.ru/gosts/gost/ 55374/ (дата обращения: 20.06.2017).

5. ГОСТ Р 55660-2013. Топливо твердое минеральное. Определение выхода летучих веществ [Электронный ресурс]. - URL: http://www.internetlaw.ru/gosts/gost/55585 (дата обращения: 20.06.2017).

6. ГОСТ 33623-2015. Топливо твердое минеральное. Метод определения равновесной влажности [Электронный ресурс]. - URL: http:// www.internet-law.ru/gosts/gost/61798/ (дата обращения: 20.06.2017).

7. ГОСТ 33503-2015. Топливо твердое минеральное. Методы определения влаги в аналитической пробе [Электронный ресурс]. URL: http://www.internet-law.ru/gosts/gost/61865/ (дата обращения: 20.06.2017).

8. Калякин С.А., Булгаков Ю.Ф. Пожаровзрывоопасность отложений угольной пыли // Научный вестник НИИГД Респиратор. - 2012. - № 1. - С. 14-27.

9. Калякин С.А. Анализ пожаровзрывоопасности угольной пыли // Научный вестник НИИГД Респиратор. - 2012. - № 1. - С. 27-35.
10. Пожаровзрывоопасность веществ и материалов и средства их тушения: справ.: в 2 кн. / А.Н. Баратов, А.Я. Корольченко, Г.Н. Кравчук [и др.]. - М.: Химия, 1990.

11. Корольченко А.Я. Пожаровзрывоопасность промышленной пыли. - М.: Химия, 1986. - 216 с.

12. Айруни А.Т., Клебанов Ф.С., Смирнов О.В. Взрывоопасность угольных шахт. - М.: Горное дело, Киммерийский центр, 2011. - 264 с.

13. Технический регламент о требованиях пожарной безопасности: Федеральный закон от 22 июля 2008 года № 123-Ф3 (с изменениями на 29 июля 2017 года) [Электронный ресурc]. - URL: http://www.consultant.ru/ document/cons_doc_LAW_78699/_дата обращения 20.06.2017).

14. ГОСТ 12.1.044-89. Пожаровзрывоопасность веществ и материалов. Номенклатура показателей и методы их определения (с изменением № 1) [Электронный pecypc]. - URL: http://npopris.ru/ wp-content/uploads/2015/03/ГОСТ-12.1.044-89.pdf (дата обращения: 20.06.2017).

15. Корольченко А.Я., Корольченко Д.А. Пожаровзрывоопасность веществ и материалов и средства их тушения: справочник: в 2 ч. - 2-е изд., прераб. и доп. - М.: Пожнаука, 2004.

16. Информационный бюллетень Федеральной службы по экологическому, технологическому и атомному надзору / Управление по надзору в угольной промышленности // Угольная промышленность. 2016. - № 4 (85). - С. 1-7.

17. Тарзанов И.Г. Итоги работы угольной промышленности России за январь - декабрь 2015 года // Уголь. - 2015. - № 3. - С. 58-72. DOI: $10.18796 / 0041-5790-2015-12-58-72$ 
18. Тарзанов И.Г. Итоги работы угольной промышленности за январь - июнь России 2016 года // Уголь. - 2016. - № 9. - С. 46-62. DOI: 10.18796/0041-5790-2016-9-46-62

19. Носенко В.Д. Как исключить взрывы метана в шахте // Уголь. - 2016. - № 6. - С. 37.

20. Бабкин В.А. Развитие угольной промышленности Российской Федерации на примере инновационного кластера Кемеровской области «Комплексная переработка угля и техногенных отходов» // Уголь. - 2016. - № 3. - С. 46-62. DOI: $10.18796 / 0041-5790-2016-3-50-52$

21. Промышленная безопасность предприятий минерально-сырьевого комплекса в XXI веке // Безопасность труда в промышленности. - 2017. - № 1. C. $82-87$.

22. Забурдяев В.С. Технологические решения по предотвращению образования взрывоопасных смесей в шахтах // Безопасность труда в промышленности. 2016. - № 12. - С. 26-31.

23. Машинцов У.А., Котлеревская Л.В., Криничная Н.А. Технология повышения безопасности в угольной шахте // Известия Тульск. гос. ун-та. Технические науки. - 2014. - Вып. 9, ч. 2. - С. 168-172.

24. Ордин А.А. О необходимости изменения горного законодательства и нормативных актов для предотвращения взрывов метана на угольных шахтах России // Уголь. - 2016. - № 6. - С. 38-41. DOI: 10.18796/0041-5790-2016-6-38-41

25. Zeyang Song, Claudia Kuenzer. Coal fires in China over the last decade: A comprehensive review // International Journal of Coal Geology. - 2014. - Vol. 133, 1. - P. 72-99. DOI: $10.1016 /$ j.coal.2014.09.004

26. Karaoulis M., Revil A., Mao D. Localization of a coal seam fire using combined self-potential and resistivity data // International Journal of Coal Geology. - 2014. Vol. 128-129. - P. 109-118. DOI: 10.1016/j.coal.2014.04.011

27. Бойко Е.А. Комплексный термический анализ твердых органических топлив: моногр. - 2-е изд. Красноярск, 2006. - 407 с.

28. Сазанов Ю.Н. Термический анализ органических соединений. - СПб.: Изд-во Политехн. ун-та, 2016. - $368 \mathrm{c.}$

29. The handbook of Thermal. Anal. Cal. / Eds. M.E. Brown, P.K. Gallagher. - Amsterdam: Elsev., 2008. - Vol. 5. - 827p.

30. Maryandyshev P.A., Chernov A.A., Lyubov V.K. Thermogravimetric and kinetic investigations of peat and hydrolytic lignine // International Journal of Experimental Education. - 2014. - № 12. - C. 20-27.
31. Xue Y., Liu J., Liang J. Correlative study of critical reactions in polyacrylonitrile based carbon fiber precursors during thermal-oxidative stabilization // Polymer Degradation and Stability. - 2013. - Vol. 98. - P. 219-229. DOI: 10.1016/j.polymdegradstab.2012.10.018

32. Совершенствование требований к показателям углей для пылевидного сжигания на ТЭС и методов их опробования / Н.В. Чернявский, А.В. Косячков, Ю.Н. Филиппенко, Е.В. Рудавина, А.Н. Воронов // Технічна теплофізика та промислова теплоенергетика. 2013. - Вып. 5. - С. 137-149.

33. Уэндландт У. Термические методы анализа / пер. с англ. под ред. В.А. Степанова, В.А. Берштейна. М.: Мир, 1978. - 526 c.

34. Применение методов термического анализа при производстве пожарно-технических экспертиз / Л.В. Дашко, А.В. Довбня, В.Ю. Ключников, Г.В. Плотникова // Вестник Восточно-Сибирского института МВД России. 2012. - № 1 (60). - С. 59-64.

35. Применение термического анализа при исследовании и экспертизе пожаров: методические рекомендации / Е.Д. Андреева, М.Ю. Принцева, С.А. Кондратьев, И.Д. Чешко. - М.: ВНИИПО, 2013. - 60 с.

36. Чешко И.Д. Экспертиза пожаров (объекты, методы, методики исследования) / под науч. ред. Н.А. Андреева; СПбИПБ МВД России. - 2-е изд., стер. - СПб., 1997. - 562 с.

37. Research on characteristic parameters of coal dust explosion / Weiguoa Cao, Liyuana Huang, Jianxinb Zhang, Sen Xu, Shanshana Qiu, Feng Pan // Procedia Engineering. - 2012. Vol. 45. - P. 442-447. DOI: 10.1016/j.proeng.2012.08.183

38. Melody S.M., Johnston F.H. Coal mine fires and human healf: What do we now? // International Journal of Coal Geology. - 2015. - 152. - P. 1-14. DOI: $10.1016 /$ j.coal.2015.11.001

39. Tolvanen H., Kokko L., Raiko R. Fast pyrolysis of coal, peat, and torrefied wood: Mass loss study with a drop १ tube reactor, particle geometry analysis, and kinetics modeling // Fuel. - 2013. - Vol. 111. - P. 148-165. DOI: $10.1016 /$ j.fuel.2013.04.030.

40. Filho S., Gomes C., Milioli F.E. A thermogravimetric analysis of the combustion of a Brazilian mineral coal [Электронный ресурс] // Quím. Nova. - 2008. - Vol. 31, № 1. - P. 98-103. - URL: http://www.scielo.br/scielo.php? script $=$ sci_arttext\&pid=S0100-40422008000100021\&lng=en\& nrm=iso (дата обращения: 20.06.2017).

41. ГОСТ Р 56721-2015. Пластмассы. Термогравиметрия полимеров. Ч. 1. Общие принципы [Электронный pecypc]. - URL: http://www.internetlaw.ru/gosts/gost/61681/ (дата обращения: 20.06.2017).

Please cite this article in English as:

Rodionov V.A., Pikhkonen L.V., Zhikharev S.Ya. Dispersion of the G-type coal dust of the Vorgashorskoe field and its influence on the thermal destruction process. Perm Journal of Petroleum and Mining Engineering, 2017, vol.16, no.4, pp.350-356. DOI: 10.15593/2224-9923/2017.4.6

Просьба ссылаться на эту статью в русскоязычных источниках следующим образом:

Родионов В.А., Пихконен Л.В., Жихарев С.Я. Дисперсность каменноугольной пыли марки Ж Воргашорского месторождения и её влияние на процесс термической деструкции // Вестник Пермского национального исследовательского политехнического университета. Геология. Нефтегазовое и горное дело. - 2017. - Т.16, №4. - C.350-356. DOI: 10.15593/2224-9923/2017.4.6 